\title{
Thanatology: The Igbo/African Metaphysics Sense and Value of Death
}

\author{
Matthew C. Chukwuelobe \\ Department of Philosophy, University of Nigeria, Nsukka, Nigeria \\ Email: mchukwuelobe27@yahoo.co.uk
}

Received September $18^{\text {th }}, 2013$; revised October $18^{\text {th }}, 2013$; accepted October $26^{\text {th }}, 2013$

\begin{abstract}
Copyright (c) 2014 Matthew C. Chukwuelobe. This is an open access article distributed under the Creative Commons Attribution License, which permits unrestricted use, distribution, and reproduction in any medium, provided the original work is properly cited. In accordance of the Creative Commons Attribution License all Copyrights (C) 2014 are reserved for SCIRP and the owner of the intellectual property Matthew C. Chukwuelobe. All Copyright $@ 2014$ are guarded by law and by SCIRP as a guardian.
\end{abstract}

\begin{abstract}
This work aims at exploring the Igbo/African metaphysical sense of death and its traditional value and inter-communality. In this study, I intend to use the Igbo as a paradigm for an African experience of death. I begin by explaining that while thanatology is the systematic study of death, metaphysics is a study of reality as it concerns the phases of human existence from life to death. In doing so, I want to examine the African being in its wholeness. Interestingly, African philosophy conceives of being as dynamic and a force to be record. The African world itself is best described as one of becoming: it is a world where there are constant interactions between the dead and the living, between the spirit-land and the human world. Thus, existence-in-relation aptly depicts the African view of life and reality. For the Igbo, however, life and death are intimately connected. To the extent that the latter paves the way to the ancestral dwelling, it is an urgent longing to join his forebears. Ultimately, the Igbo/African attaches a great value to ancestral abode where death makes possible. Through initiation the Igbo anticipates death. Only then does death become a phenomenon of life, entering the Igbo ontological being. Thus death for the Igbo does not constitute an end. Rather it intimates an authentic being (another beginning), which expressly embodies eschatology. I argue that eschatology aims at overcoming time.
\end{abstract}

Keywords: Death; Thanatology; Igbo/African Metaphysics; Value; Life; Rebirth

\section{Introduction}

The question concerning African metaphysics is intimately tied with African philosophy as a whole. There was a time when such question was raised by scholars and thinkers alike. In the $21^{\text {st }}$ century when African philosophy has come of age, "it would be superfluous and fruitless to embark once more on the old debate: whether there is an African philosophy. Doing so would flog the issue. In this respect, we presume that there is an African philosophy" (Chukwuelobe, 1995: p. 25).

Exploring African metaphysics of death demands that we understand metaphysics and its scope within the context of philosophy itself. Generally, metaphysics as a science concerns itself with the ultimate understanding of reality. It therefore "involves a synthesis of all experiences in order to achieve a coherent whole which gives a complete picture of reality" (Ozumba, 2004: p. 2). By doing so, African metaphysics aims not only at questioning the tradition from which it emerges, but to transcend it through an interpretive and critical activity of the African thinker. In other words, it is "the African way of perceiving, interpreting and making sense out of interactions, among beings, and reality in general” (Ibid: p. 2). It is expressly this sense of metaphysics that will inform the African metaphysics of death with a view to inserting it within a coherent metaphysical perspective. The term thanatology which appears in our title is from a Greek word thanatus, death. So, thanatology is a systematic inquiry of the nature of death. This investigation itself anchors on life which provides a springboard for probing into the strange but intriguing terrain of death.

Life as well as death permeates the African existential world. Death paves the way to new birth; it makes possible the African affiliation to the ancestral abode and, hence, to new birth. To this extent, death for the African is as important as life itself. It is expressly in this sense that death has a value for the Igbo/ African. As complementary modes of being, death and life provide an apt subject matter for metaphysics - an inquiry into reality. Interestingly, "the Igbo see things in complementary dualities. This is evident in the perception of society as made up of oha na eze, ikwu na ibe, nwoke na nwanyi (people and king, man and woman)" (Nwoga, 1984: p. 22). Understanding African experience and its holistic framework will enable us to explore the meaning - that is, the Igbo/African metaphysics - of death. Given the inclusive and holistic view of Igbo cosmology, it can easily be understood why and how the Igbo life-experience relates intimately to the question of death.

Admittedly, Igbo thought organizes itself within the ambience of experienced life. The Igbo are naturally pragmatic people, who "live existence rather than indulge in futile mental speculation about it” (Egbujie, 1977: p. 141). It is precisely this existential milieu-experienced life-that lends meaning and vitality to African/Igbo thought. Because of this, any inquiry into Igbo experience raises the question: how do the Igbo/Afri- 
can understand this experience/reality? The Igbo "brush with experience" is personal and egocentric. It implies that the Igbo are deeply steep in experience. Thus, the meaning and truth of personal experience of the Igbo, which reminisces existentialist thought, requires personal commitment and concern for the phenomenon involved. This in turn makes possible human transformation.

However, the Igbo does not exist for himself alone; he is not an island. Rather, he derives vitality and life-force from his immediate community. It stands to reason, therefore, that his relationship to these phenomena depends on the degree to which he is able to identify with the community. Hence it is within this community that the Igbo lives and has his being.

To say, however, that the Igbo have personal experience of reality/phenomenon does not mean that this experience or reality is completely individual in nature. Rather, philosophic experience, like the religious experience to which it is ultimately and intimately connected, is not an individual property but a shared and cooperative one... The experience of God, ancestors, life and death in Igbo culture is therefore a shared one, and this experience is valuable for all those who identify themselves with it (Anyanwu, 1988: p. 88).

Our approach to this topic falls under two headings: The first part deals with the African/Igbo experience of death. It primarily examines the Igbo phenomenon of death in relationship to the ancestor and authentic existence/being. The second section explores the African/Igbo hermeneutics of death, which itself is an expression of the African metaphysics of death. It considers, among other things, the Igbo anticipation of death and death, eschatology and time.

\section{The Igbo/African Experience of Death}

For the Igbo/African death evokes, on the one hand, a sense of estrangement and disruption, and, on the other hand, an urgent longing to join one's forebears. The life of the Igbo determines the extent to which this yearning for ancestral dwelling is possible. However, death becomes a "going-to-the-spirit land" (ala mmo). Ultimately, this Igbo sense of "going-home" through death demand further reflection since it is an intrinsic part of the overall Igbo attitude to the phenomenon of death.

Even as death marks a "disruption" in the rhythm of life, it enhances life itself. Only then does it provide essentially an access to the spirit-land (ala $\mathrm{mmo}$ ), which, for the Igbo, embodies an authentic life. So the African at the same time both acknowledge and deny the disruption of death. "A person dies and yet continues to live: he is a living-dead” (Mbiti, 1969: p. 161). However, the sense of the living-dead itself evokes the idea of a continual dialectic play of life and death. Even as death mediates the visible and invisible worlds, the Igbo dwell within its ontological and dialectic framework. This is precisely because man at the centre of the cosmos lives out the two existential levels of Igbo world-the human (ala madu) and the spiritual (ala mmo).

Interestingly, the spirit land and the human world intermingle. This essentially and ontologically characterizes the holistic nature of Igbo thought. To this extent, death does not constitute human finality (Egbujie, 1977: p. 141), but marks a transition; it is "the other beginning" which is "the first beginning." The rhythms of birth and death, therefore, are not to be construed "....as the definite beginning and end of existence but rather only as 'crossings' in an eternal continuum of existence..."
(Shelton, 1968: p. 162). This crossing or interpenetration of the visible and invisible world implies that:

The land of the living is not far removed from the domain of the ancestors. There is coming and going between them, especially at festivals and when an old man dies, because an old man is very close to the ancestors. A man's life from birth to death is a series of transition rites which brings him nearer and nearer to the ancestors (Achebe, 1978: p. 85).

These transition rites could be viewed as man's continuous dying, is expressed in a series of initiations that punctuates his life. Therefore, initiations itself is an aspect of Igbo anticipation of death. This be so, death becomes a phenomenon of life, which enters the Igbo existential and ontological being.

Death is not merely a phenomenon of life, it is, and more importantly so, a necessity. Proverbially, "death is a debt which everyone owes" (onwu bu ugwo madu ji). It is a debt which remains continually "outstanding." The inevitability of death, however, does not lead the Igbo to despair and fear. Rather it calls for an effort to reflect on the meaning of existence. Intriguingly, "death... enjoys the incontestable advantage over life in that it is necessary, it was not inevitable that life be given, but as soon as it appeared death had to follow" (Zahan, 1979: p. 39). Agreeably, while death is a necessity, life itself is a possibility.

At this point it is good to note that the Igbo ascribe necessity to death as it pertains to old age. Such a death is conceived as onwu-chi (death which is ordained by one's chi-the god in every man). Invariably, onwu-chi, which evokes the sense of inevitability of death, makes possible man's entry into ancestral dwelling. Without onwu-chi the Igbo can neither join the ancestors nor attain authentic being/existence.

Obviously the sense of Igbo authentic existence/being raises the following questions: How do the Igbo reach authentic existence? How is authentic existence constituted? Why do the Igbo yearn for authentic being? We shall note that for the Igbo authentic being is earned through individual achievement and status. To this extent, the craving for individual status/ achievement, which is intimately tied to authentic existence, is purposeful and significant. Death does not change man's individuation and social status; a person remains as he is in the spirit land. It is only reasonable then that the Igbo make the best the human world. By doing so, he paves the way for authentic existence/ being.

The Igbo look forward to the next world as being much the same as this... They picture life there to be exactly as it is here; the earth is similar... People in spirit-land have their ordinary occupations, the farmer his farm... The king remains king... (Leonard, 1968: pp. 185-186).

The earthbound nature of death, is a symbol and, as such, is meaningful when viewed from the Igbo holistic thinking which to harmonize matter and spirit, the visible and the invisible. Death neither signals a dismantling of man's being nor does it suggest an "end". Instead it represents one's engagement in 'the other beginning,' which itself is authentic existence/being - the ancestral dwelling. As we pointed out earlier, man does not inherit authentic existence/being, ancestor-ship. Rather he earns it by continuously creating and affirming himself. This affirmation of self, which chi makes possible, finds expression in the individual's effort to achieve authentic being. Becoming an ancestor is the dream and longing of every Igbo; his existential striving is geared towards reaching this goal. Wholeness or authentic being depends on the induction of the Igbo into the an- 
cestral abode which is made possible and preceded by individual achievement. However, it is not everyone that attains this status.

Not just anyone can become an ancestor. The society of the living 'directs' towards this paradise only those dead who satisfy certain well-defined conditions... The ancestor is, first of all, a man who has reached a great age and who has acquired along with longevity a profound experience of people and things. He is thus distinguished from people less advanced in age and whose credulity and inexperience in life classify them with children or youths; the latter are usually not given elaborate funerals and are never the focus of cult (Zahan: p. 49).

Since death for the Igbo is not an "end" but the "other beginning," the yearning for ancestral dwelling becomes a tending towards a mythical terrain. Thus this mythic state of being with one's ancestors opens the Igbo ontologically to a more notion of death as access to authenticity. Arguably, the Igbo accept death because it provides access to 'fullness of life in the ancestral dwelling.

The Igbo experience of death permeates the entire fabric of life itself. Understanding death, therefore, leads to thinking about life. Ultimately, the Igbo hermeneutics of death, which we shall now explore in the next section, will essentially establish the dialectic between life and death.

\section{Igbo/African Thinking Death and Value}

Death enjoys quite a remarkable tie with life to such a degree that the place where it enters life is the terrain of "existential possibility.” It is to be noted that for Heidegger, possibility-in the sense of an existential-has a new meaning of being. Quite to the contrary, it is not to be construed as the categorical possibility, which underlies actuality and necessity of vorhanden (present; at hand) entities. Rather it is ontological (Heidegger, 1962: p. 63). The present section therefore aims at interpreting death within the framework of anticipation, eschatology, time and value. In doing so, we intend to explore the African/Igbo metaphysics of death and value.

\section{African/Igbo: Anticipation and Death}

The necessity of death and its 'this-worldliness' evokes in the Igbo a sense of anticipation and the need to prepare for it. Tying death to authentic existence-as epitomized by the ancestral status - enables the Igbo to overcome the fear which normally accompanies death. For the Igbo, however, the inevitability death finds its utmost and pervasive expression in anticipation as the "advancing-towards-death." This is evident in certain presentiments and various symbols of initiation which represent different ontological possibilities of death. Evidently, the phenomenon of 'advancing-towards' makes death "alive” in an Igbo. In this way, the Igbo accept the necessity of death.

Presentiment itself, as an aspect of the Igbo phenomenon of anticipation, comes with certain signs which point to the imminence of death. These portents find expression in appearance of certain birds, such as the owl (ubian bu onwu), whose cry presages death. It is the harbinger of death because its cry is an omen the death is imminent in the homestead. The Igbo also associate flood, shooting stars or comets with the death of a king or noble. Thus, "onwu ama eze" ("death does not recognize/ know a king”) is an Igbo saying which that death does not discriminate between persons and belongs to all without exception.
The Igbo essentially lives through different existential phases which are situated between life and death. Initiation (ikpobata, i.e. "letting-in") marks such phase/stage, which begins at birth and culminates at death - the initiation of all initiations. Notably, initiation as a process entails a symbolic dying and rising. For the Igbo, initiation punctuates life itself; an individual is "let-in" at crucial moments. These include the naming ceremony (igo aha), puberty, age-grade (ogbo), and masquerade society (otum mmanwu). Every initiation evokes a sense of dying/death. Initiation as an anticipation of death ritually intimates death and, in turn introduces a person to a new mode of being. In other words, an initiation is a symbolic death: “... any passage from one mode of being to another implies necessarily a symbolic act of dying” (Eliade, 1976: p. 38). Symbolic death is clearly an expression of the initiation into the masquerade society (otum mmanwu, i.e. the incarnate dead).

Through the initiation into the mmanwu cult-involving elaborate ordeals of various magnitude and rites of symbolic death - the Igbo emerges with great vitality and knowledge of the world of the dead. Transcending himself and his world through this new experience, man reaches his "wholeness" and in this way abolishes his natural humanity.

Initiation is accomplished and marks the death of the old man and the resurrection of a new being. This is what constitutes, strictly speaking, man's passage to knowledge. Thus, the human being goes beyond himself insofar as he acquires a new vision of himself (Zahan: p. 54).

By anticipating death in this respect, the Igbo overcome (Eliade, 1959: p. 196) the fear of death. It is only then that he becomes an authentic being. Admittedly, the Igbo lend himself to such genuine being in the act of initiation. By one estimate, initiation brings man to a great awareness of himself as a mortal being.

Underlying presentiment and initiation is the Igbo concern for preparedness and anticipation of death. These phenomena generate within an individual a sense of ontological death. Paradoxically, the interplay of life and death within the framework of anticipation “... discloses a nostalgia and, perhaps, a secret hope of attaining a level of meaning, where both (life and death) reveal themselves as aspects or dialectical stages of one ultimate reality" (Eliade, 1976: p.42).

\section{Igbo/African: Eschatology, Time and Value}

Having examined the African ontological perspective of death, we shall explore time within the overall framework of Igbo death-reflection. Evoking an eternal return the Igbo funeral rites and rituals, charged with religious and eschatological symbols, make possible the "other beginning"-new life. This new beginning finds expression in the Igbo idea of reincarnation (ilo uwa).

Like any Igbo phenomenon, time is understood within the framework of existential concern for life itself. In a sense, time does not exist outside the Igbo traditional and cultural milieu. Invariably, the Igbo know time as it is constituted by event. In other words, the Igbo does not preexist time; he is contemporaneous with time. It is only this sense that time becomes meaningful.

Instead of the onward trend of time to the infinite (a linear conception of time), the Igbo speak about the passage of life from one level to another, from birth...to death and re-birth. In this vital concept of time or reality with its aesthetic qualities, 
the depth of lived experience replaces the abstract precision of impersonal scientific time; and this depth of lived experience is a field of existential concern. Time, in Igbo culture, is a totality of living which becomes deeper and richer with age and experience (Anyanwu: p. 93).

Because time for the African touches on events and existential being, it is deeply grounded in finitude. However, he concerns himself not with distant past, present and future, but with the immediate time. Again, rather than giving prominence to the future, where successive link through birth take place, the African/Igbo inclines to the past.

Being oriented towards the past, the African finds the justification and meaning of his actions not in the future but in time already elapsed. His reasoning is thus "regressive": "I do this because my forefathers did it. And they did it because our ancestors did it.” The profound and necessary connection between present activity and the past thus appears. The aim is to trace the present from the past and thereby justify it (Zahan: p. 47).

It has variously been argued that the African does not conceive of the future precisely because he thinks only of his immediate concern/experience. By so doing, the future which does not constitute his experienced life is not his main concern. However, it can even be argued that the technique used by the diviner (dibia afa) to interpret reality, whereby he projects to the future, proves this case as an exception.

Unlike the western idea of time- - with definite present, past and infinite future-the African/Igbo eschatology is not linear. Rather it is "cyclical” or, possibly relational. Man's life marks an ontological rhythm of birth and death, "which are not to be considered as the definite beginning and end of existence but rather only as 'crossing' in an eternal continuum of existence which is... dynamic" (Shelton: p. 165). Within the framework of these three moments of time the woman's role as a mother becomes significant. Living in the present, she immerses herself both in the past and future simultaneously. Because she gives birth to a child, who the African/Igbo conceive of as one of the ancestors, a woman is a link between the past and the future. Thus, a woman is "the crossroad where future and past, death and life intersect" (Zahan: p. 45). Hence a link is established between life and death-present, past and future-which are ontologically contained. Remarkably, for the Igbo/African death is an opening "into the abode of the ancestors" (Abanuka, 1994: p. 45). The value and significance of death lie expressly in the Igbo/African understanding that it paves the way for the ancestral dwelling. In Igbo/African thinking of rebirth, there is essentially an ontological continuity between life in the ancestral abode and life on earth made possible by death.

Underlying the Igbo thinking of eschatology is the idea of "overcoming," the arresting of time within the dialectical play of life and death. For the Igbo eschatology, which essentially marks a new beginning, is a synthesis of life and death. In this eschatology, "overcoming" is possible within the context of a ritual. Transcending time-overcoming the temporal terrainenables the Igbo to enter the domain of the sacred or the mythical. His entrance in turn makes it possible for him to overcome the "spirit of revenge of time" in the true Nietzsche's sense.

Entering the terrain of the sacred- "the other beginning," through a ritual-the Igbo transcends the realm of the profane, where time wields its influence. Only then is he able to dwell in the region of authentic time, the realm of sacred and mythical time. This authentic time can only be realized within a ritual setting. And within such a framework the three dimensions of time, present, past and future collide. As a historical being, the Igbo finds himself thrown into time, where death marks an end and his destruction. But eschatology holds the promise of his saving grace.

Finally from the perspective of Igbo eschatology, death is no longer an end in which time evokes terror and limits man. Rather it is now an initiation into new realm, another beginning. It is expressly an 'eternal return' to a more primordial and authentic time of origin. It is obviously an overcoming - a deconstruction of profane time. We can even argue that Da-sein (man) does not die to the degree that it anchors in this time of origin-eschatology. Thus the Igbo continually recover primordial time within the framework of the eschatological rite-mortuary rite (ikwa ozu).

\section{Conclusion}

Having come this far in this reflection, we can glean that death from Igbo/African perspective is not an end. It marks a transition which makes possible "the other beginning." Its necessity is viewed to the degree that it brings man to this "other beginning," where life has its origins. It is important, though, to bear in mind that the Igbo/African does not have two worlds. Rather, there are two levels of existence-the terrestrial and the spiritual, both in one holistic Igbo world. So, the idea of a transition can only be conceived in terms of this world/earth. Admittedly, the Igbo/African thinks death within the framework of eschatology, which has both a temporal and religious dimension.

In the same vein, it can be seen that the Igbo/African is understood from his existential circle: birth, death and re-birthcorresponding to present, past and future. Uniquely, the Igbo "circle of existence" is deeply eschatological as it is historical. Ultimately, the Igbo eschatology captures within itself the three existential moments of man-birth, death, and re-birth: present, past and future. It is a gathering of the beginning and the end. This gathering takes place within the context of the Igbo/African mortuary rite (ikwa ozu), which itself is the eschatological rite of initiation. To this extent, the Igbo/African thinking of eschatology is an intimation of the first and the other beginning. This expressly captures the pristine nature of existence through the path of "eschatology," the circular reversal in which the beginning overtakes the end. Thus the Igbo/African eschatology is an attempt to overcome time. In doing so, death does no longer mark an end; it is the other beginning.

Finally, from the Igbo/African perspective death is not a possibility but a necessity. It is a necessity precisely because death is an opening into another level of Igbo/African existence, the spiritual. Here lies the value of death for the Igbo/African. Given, therefore, the holistic dimension of Igbo thinking, man has no problem integrating the terrestrial and the spiritual levels of existence, death notwithstanding.

\section{REFERENCES}

Abanuka, B. (1994). A new essay on African philosophy. Onitsha: Spiritan Publications.

Achebe, C. (1978). Things fall apart. London: Heinemann.

Anyanwu, C. (1988). The meaning of ultimate reality in Igbo cultural experience, in Ultimate reality and meaning (pp. 84-101).

Chukwuelobe, M. (1995). Language and Igbo philosophy: Towards an Igbo Phenomenology of language in Philosophy Today (pp. 25-30).

Egbujie, I. (1976). The hermeneutics of African traditional culture. 


\section{C. CHUKWUELOBE}

Ph.D. Dissertation, Boston: Boston College.

Eliade, M. (1959). The sacred and the profane Tr. Willard R. Trask. New York: Harcourt, Brace and Company.

Eliade, M. (1976). Occultism, witchcraft, and cultural fashions. Chicago: The University of Chicago Press.

Heidegger, M. (1962). Being and time. Tr. John Macquarrie \& Edward Robinson. New York: Harper \& Row, Publishers.

Leonard, A. (1968). The lower niger and its tribes. London: Frank Cass.

Mbiti, J. (1976). African religions and philosophy. London: Heine- mann.

Nwoga, D. (1984). Nka na nzere: The focus of Igbo world. Ahiajoku Lecture, Owerri: Culture Division, Ministry of Information, Culture, Youth and Sports.

Ozumba, G. (2001). African traditional metaphysics in Quodlibet Journal (pp. 2-20)

Shelton, A. J. (1968). Causality in African thought: Igbo and others. Practical Anthropology, 15, 157-169.

Zahan, D. (1979). The religion, spirituality, and thought of traditional Africa. Tr. K. Ezra and L. Martin. Chicago: University of Chicago Press. 